\title{
Spongioplasty with Dartos Flap Coverage in the Snodgrass Technique of Hypospadias Repair
}

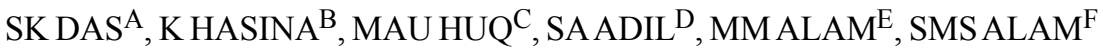

\author{
Summary: \\ Objective: The aim of the study is to evaluate the role of \\ spongiosal tissue with dartos flap coverage for preventing \\ Urethrocutaneous Fistula (UCF) formation in the Snodgrass \\ technique.
}

Materials and Methods: It is a prospective study, performed on 35 patients of mid penile and distal hypospadias aged 15 months to 144 months who underwent urethroplasty in the Snodgrass technique using spongiosal tissue and dartos flap for neourethral coverage.

Results: Among 35 patients, Age ranged from 15 months to 144 months (mean 85.94 months). Chordee was corrected by penile degloving alone in 11 patients, partial mobilization of urethral plate with spongiosum in 20 patients and 4 patients required dorsal plication. Glans groove was deep in

\section{Introduction:}

In 1994, Snodgrass introduced the tubularized incised plate (TIP) urethroplasty technique for hypospadias repair. ${ }^{1}$ It has good cosmetic and functional outcomes with a low rate of complication. Neourethral covering is an important contributing factor in terms of fistula formation in urethroplasty. ${ }^{2}$ Different tissues have been described in the literature as an intermediate layer to cover the neourethra using dorsal, ${ }^{3}$ lateral, single or double ${ }^{4}$ dartos flaps, ventral based dartos flap, ${ }^{5}$ scrotal dartos flap, ${ }^{6}$ spongioplasty ${ }^{7-9}$ and tunica vaginalis flaps. ${ }^{10,11}$ The corpus spongiosum provides a well

a. Dr. Sahadeb Kumar Das, Assistant Professor, Dept. of Pediatric Surgery, Khulna Medical College, Khulna.

b. Prof. Kaniz Hasina, Professor, Dept. of Pediatric Surgery, Dhaka Medical College, Dhaka.

c. Prof. Md. Ashraf Ul Huq, Professor and Head, Dept. of Pediatric Surgery, Dhaka Medical College, Dhaka.

d. Dr. Syed Abdul Adil, Assistant Professor, Dept. of Pediatric Surgery, Dhaka Medical College, Dhaka.

e. Dr. Md. Mahbubul Alam, Assistant Professor, Dept. of Pediatric Surgery, Dhaka Medical College, Dhaka.

f. Dr. S. M. Shafiqul Alam, Associate Professor, Dept. of Anesthesiology and ICU, Dhaka Medical College, Dhaka.

Address of Correspondence: Dr. Sahadeb Kumar Das, Assistant Professor, Dept. of Pediatric Surgery, Khulna Medical College, Khulna, Bangladesh. Tel: +88 01710894635 Email: sahadebk8@yahoo.com

Received: 5 Nov. 2018

Accepted: 20 Dec. 2019
19 patients, shallow in 13 patients and no groove noticed in 3 patients. Sixteen patients had narrow urethral plate $(<8 \mathrm{~mm})$ and 19 patients had adequate urethral plate $(>8 \mathrm{~mm})$. Urethrocutaneous Fistula (UCF) was encountered in five patients (14.28\%), meatal stenosis in two patients (5.71\%), and partial glanular dehiscence in one patient.

Conclusions: Approximation of spongiosal tissue along with dartos flap as the intermediate layer for neourethral coverage reduces fistula formation.

Key words: Hypospadias, UC fistula, Meatal Stenosis, Spongioplasty, Dartos Flap.

(J Bangladesh Coll Phys Surg 2020; 38: 64-67)

DOI: https://doi.org/10.3329/jbcps.v38i2.45629

vascularized, spongy protective covering to the normal urethra that can prevent diverticula and facilitate catheterization if required. It may aid in the natural propulsion of urine and semen. Using this spongiosal tissue to cover the neourethra may be effective for preventing fistula. The aim of the study is to evaluate the role of spongiosal tissue with dartos flap in prevention of fistula formation in patients undergoing hypospadias repair in the Snodgrass technique.

\section{Materials and Methods:}

It was a prospective study in the Department of Pediatric Surgery, Dhaka Medical College and Hospital (DMCH), Dhaka, Bangladesh between January 2015 to December 2016. This study included children with mid penile and distal (coronal \& distal penile) hypospadias. Patients underwent circumcision, urethroplasty, orthoplasty and cases of severe chordee are excluded. The principal investigator collected the data and information about the patient in a prescribed data sheet after getting written consent from the parents in a preformed consent form. A stay suture was applied to the glans by $4 / 0$ round body proline. A U-shaped incision was made around the urethral plate border and hypospadias orifice. Then circumcoronal preputial incision was made and the penis was degloved. Two parallel longitudinal incisions were made to separate the lateral edges of the urethral plate from the glans wings. The corpus spongiosum alongside the urethral plate was dissected from the underlying 
corpora cavernosa taking care not to damage either of those. The spongiosal dissection started proximal to the meatal opening and continued distally beneath the urethral plate. The distal portion of spongiosum were then detached from the glans. An artificial erection test performed to assess for residual ventral curvature. Any chordee, if present, was corrected by midline dorsal tunica albugineal plication. The incised urethral plate was tubularized using $6 / 0$ polyglactin sutures over a stent in one layer, turning all of the epithelium into the neourethral lumen. Tubularization of the urethral plate started from the proximal end carried upto midglanular level. The previously mobilized corpus spongiosum was approximated with $6 / 0$ polyglactin by suturing the edge of mobilized spongiosum. Dartos flap was taken from the dorsal preputial and penile skin that was divided in two wings and laterally twisted to cover the neo-urethra as double-layered fashion. The glans wings were approximated with no tension, and the penile skin was sutured. All patients were then circumcised. The stent was secured to the glans with the traction suture. Pressure dressing was applied in all cases with cotton guaze and adhesive tape.

First dressing was checked on $4^{\text {th }}$ POD, wound was kept open and Mupirocin ointment was applied on the wound 3 times daily for 14 days. Stent was removed on $10^{\text {th }}$ POD. Patients were discharged on $10^{\text {th }}$ POD with advice of meatal calibration and assessed on follow up.

Follow up consisted of a first visit at the end of $1^{\text {st }}$ month, second visit at the end of $3^{\text {rd }}$ month and further visit at 1 year and then annually for fistula, cosmesis, meatal stenosis and other complications. Follow up period varied from 18 months to 36 months. Conical glans, meatus near tip of the glans, vertically oriented slit like meatus, a single urinary stream, straight erection were considered as satisfactory results. The study was approved by ethical review committee (ERC) of Dhaka Medical College.

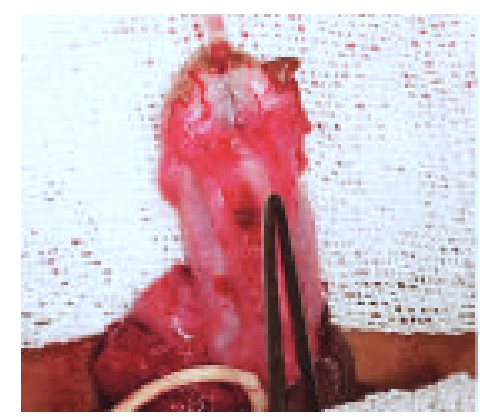

(a)

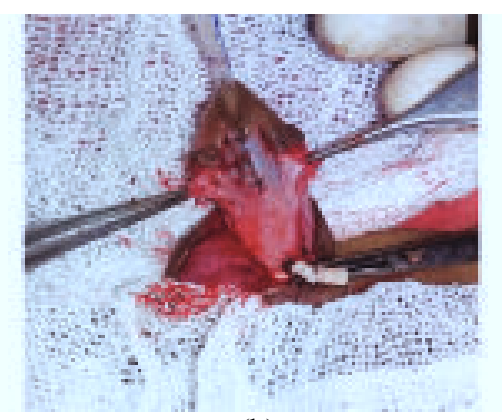

(b)

\section{Results:}

A total of 35 patients underwent urethroplasty by Snodgrass procedure using spongioplasty with dartos flap coverage of the neourethra. Age ranged from 15 months to 144 months (mean 85.94 months). Twelve patients were less than 6 years and 23 patients were more than 6 years old. The patients characteristics are showed in Table 1. Chordee was corrected by penile degloving alone in 11 patients, partial mobilization of urethral plate with spongiosum in 20 patients and 4 patients required dorsal plication. Glans groove was deep in 19 patients, shallow in 13 patients and no groove noticed in 3 patients. Sixteen patients had narrow urethral plate $(<8 \mathrm{~mm})$ and 19 patients had adequate urethral plate ( $>8 \mathrm{~mm}$ ). Operating time ranged from 98 minutes to 147 minutes (mean 126.48 minutes). All patients, except one, had a satisfactory outcome. Urethral fistula was encountered in 5 patients $(14.28 \%)$. Meatal stenosis was found in 2 patients $(5.71 \%)$ on follow up that was successfully managed by meatal dilation.Partial granular dehiscence occurred in 1 patient.

Table-I

Patients Characteristics

\begin{tabular}{lcc}
\hline & $\mathrm{n}=35$ & Percentage \\
\hline Mean Age (Month) & 85.94 & \\
Hypospadias site: & & \\
Coronal & 15 & $42.85 \%$ \\
Distal penile & 8 & $22.85 \%$ \\
Mid penile & 12 & $34.28 \%$ \\
Chordee: & & \\
Absent & 10 & $28.57 \%$ \\
Mild(<30Ú) & 17 & $48.57 \%$ \\
Moderate(30Ú - 60Ú) & 8 & $22.85 \%$ \\
Complications: & & \\
Fistula & 5 & $14.28 \%$ \\
Meatal stenosis & 2 & $5.71 \%$ \\
Glanular dehiscence & 1 & $2.85 \%$ \\
\hline
\end{tabular}

Fig.-1: a). Corpus spongiosum after penile degloving b). Mobilized corpus spongiosum on both sides c). Spongiosal coverage over the neourethra. 


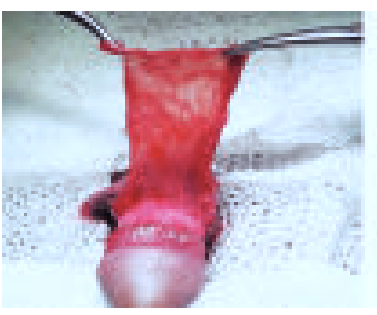

(a)

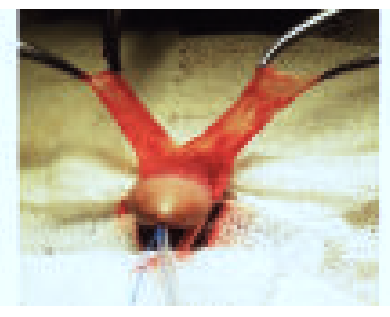

(b)

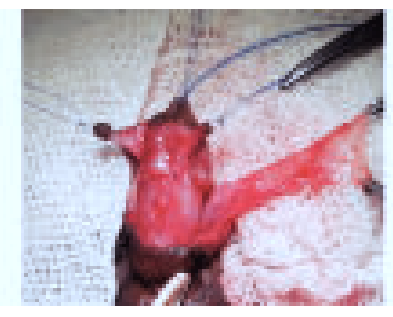

(c)

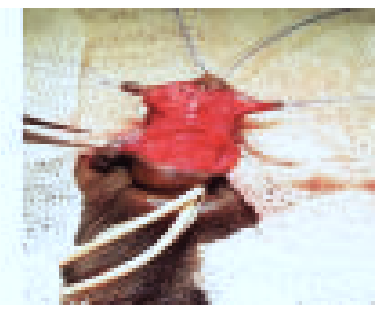

(d)

Fig.-2: a). Dartos flap taken from dorsal preputial and penile skin b). Splitted in the midline c). Transferring these two flaps to the ventral side over the neourethra d). Suturing of the two layers in double-layered fashion.

\section{Discussion:}

The ideal age for repair of hypospadias is 6-18 months. ${ }^{12}$ In this study, the mean age was 85.94 months. The mean age was higher than the ideal age for hypospadias repair. This may be due to the fact that people living in low socio-economic condition are not aware of their health. UCF is the srtiking complication of hypospadias repair with an incidence varying from 5\% to $44 \% .{ }^{13}$ Different tissues and techniques have been described to solve this problem.

The vascularized dartos flap is suitable for second layer coverage of the neourethra. There have been many reports of different techniques for harvesting and applying the dartos flap. In this study, dartos flap was taken from dorsal preputial and penile skin and used for neourethral coverage in the same technique. The dartos flap was divided in the middle without disturbing its vascularity and transferring these two flaps to the ventral side over the neourethra and suturing of the two layers in double-layered fashion (bat wing). Using this technique, different investigators from different studies observed no fistula in double dartos flap coverage but in case of single dartos flap, observed different rate of fistula formation. ${ }^{3,14-19}$ On the other hand, Elsayed et al. reported no significant difference in subsequent Urethrocutaneous Fistula (UCF) between a doublelayered dorsal dartos flap and single layer for covering the urethra as a part of TIP urethroplasty for repairing hypospadias. ${ }^{20}$

Spongiosal tissue has been used by many surgeons to prevent fistula and other complications from its introduction in 2000 by Beaudoin ${ }^{7}$ and Yerkes. ${ }^{21}$ Yerkes et al. noticed no fistula in any of the patients of spongioplasty in a different urethral repair technique. ${ }^{21}$ After that, spongiosal tissue was used by different investigators and different rates of fistula formation were observed. Dodat et al. in 2003 observed no fistula in any of the 37 patients of anterior hypospadias using spongiosal tissue for neourethral coverage. ${ }^{22}$ Hayashi et al. found 3 complications out of 37 patients that underwent spongioplasty in the TIP urethroplasty. ${ }^{23}$ In a series of 500 patients, Sarhan et al. performed urethroplasty in Snodgrass technique using dartos flap, spongioplasty or a combination of both for neourethral coverage and observed a statistically significant decrease in fistula formation in patients in which spongioplasty was done in comparison with patients in which it was not done. ${ }^{24}$ By using the spongiosal tissue in addition to dartos flap wrapping, Almodhen et al. ${ }^{25}$ and Bilici et al. ${ }^{26}$ did not observe fistula in any of the cases of 32 patients and 86 patients respectively. Bhat et al. reported 2 fistulae in a series of 40 patients of TIP urethroplasty using spongioplasty in addition to dartos flap coverage. ${ }^{27}$ In the present study, we found 5 (14.28\%) fistula among 35 patients using dartos flap plus spongioplasty in the TIP urethroplasty. However, Kocvara et al. reported a higher complication rate $(40 \%)$ using the spongiosal tissue for neourethral coverage of 37 patients. $^{28}$

Spongiosum is a healthy vascular tissue that provides good support to the neourethra if it is dissected and apposed properly. It decreases tension on the sutures line especially during erections. Another advantage of spongioplasty is restoration of a urethra by nearly normal structure.

The strengths of this study includes its prospective type, patients belonged to similar socio-economic status with average nutritional condition of the patients, procedure was performed in a single centre in similar circumstances and care taken in similar environment in general ward and with adequate follow-up.

\section{Conclusion:}

The spongiosal tissue can be preserved with careful degloving of the penis during uerthroplasty. Considering the results of this study, approximation of the corpus spongiosum along with dartos flap as an 
intermediate layer in urethral coverage as part of Snodgrass technique reduces the rate of fistula formation. This technique provides a vascular tissue for coverage of the suture lines and reduces fistula formation.

Disclosure: The study is a part of Masters of Surgery thesis of the first author under University of Dhaka. All the authors declared no competing interest.

Conflict of interest: We have no conflict of interest.

\section{References:}

1. Snodgrass WT. Tubularised incised plate urethroplasty for distal hypospadias. J Urol 1994; 151:464-465.

2. Cimador M, Pensabene M, Sergio M, Catalano P, Grazia ED. Coverage of urethroplasty in pediatric hypospadias: Randomized comparison between different flaps. Int J Urol 2013; 20:1000-1005.

3. Mustafa M, Wadie BS, Abol-Enein H. Standard Snodgrass technique in conjunction with double-layer covering of the neourethra with dorsal dartos flap is the therapy of first choice for hypospadias. Int Urol Nephrol 2008; 40:573576.

4. Yildiz A, Bakan V. Comparison of Perimeatal-Based Flap and Tubularized Incised Plate Urethroplasty Combined with Single- or Double-Layer Dartos Flap in Distal Hypospadias. Urol Int 2010; 84:265-268.

5. Soygur T, Arikan N, Zumrutbas AE, Gulpinar O. Snodgrass hypospadias repair with ventral based dartos flap in combination with mucosal collars. Eur Urol 2015; 47:879884.

6. Hayashi Y, Kojima Y, Kurokawa S, Mizuno K, Nakane A, Kohri K. Scrotal dartos flap for the prevention of the urethrocutaneous fistula on hypospadias urethroplasty. Int J Urol 2005; 12:280-283.

7. Beaudoin S, Delaage PH, Bargy F. Anatomical basis of surgical repair of hypospadias by spongioplasty. Surg Radiol Anat 2000; 22:1339-1341.

8. Delaage PH, Bargy F, Beaudoin S. Spongioplasty in the treatment of hypospadias. Progrès en Urologie 2005; $15: 1120-1123$

9. Mezzine S, Beaudoin S, Bargy F. Medium and longterm evaluation of spongioplasty in hypospadias repair. Prog Urol 2005; 15:519-523.

10. Babu R, Hariharasudhan S. Tunica vaginalis flap is superior to inner preputial dartos flap as a waterproofing layer for primary TIP repair in midshaft hypospadias. J Pediatr Urol 2013; 9 804-807.

11. Chatterjee US, Mandal MK, Basu S, Das R, Majhi T. Comparative study of dartos fascia and tunica vaginalis pedicle wrap for the tubularized incised plate in primary hypospadias repair. BJU Int 2004; 94:1102-1104.

12. Schultz J, Klykylo W, Wacksman J. Timing of elective hypospadias repair in children. Pediatrics 1983; 71:342351.

13. Retik AB, Keating M, Mandell J. Complications of hypospadias repair. Urol Clin North Am. 1980; 15:223-236.
14. Maarouf AM, Shalaby EA, Khalil SA, Shahin AM. Single vs. double dartos layers for preventing fistula in a tubularised incised-plate repair of distal hypospadias. Arab J Urol 2012; $10: 408-413$

15. Abolyosr A. Snodgrass hypospadias repair with onlay overlapping double-layered dorsal dartos flap without urethrocutaneous fistula: Experience of 156 cases. J Pediatr Urol 2010; 6:403-407.

16. Erol A, Kayikci A, Memik O, Cam K, Akman Y. Single vs. double dartos interposition flaps in preventing urethrocutaneous fistula after tubularized incised plate urethroplasty in primary distal hypospadias: a prospective randomized study. Urol Int 2009; 83:354-358.

17. Appignani A, Prestipino M, Bertozzi M, Nardi N, Falcone F. Double-cross flap protection. New technique for coverage of neourethra in hypospadias repair. J Urol 2009; 182:1521-1527.

18. Bakan V, Yildiz A. Dorsal double-layer dartos flap for preventing fistulae formation in the Snodgrass technique. Urol Int 2007; 78:241-244.

19. Kamal BA. Double dartos flaps in tubularized incised plate hypospadias repair. Urology 2005; 66:1095-1098.

20. Elsayed ER, Zayed AM, Sayed DE, Adl ME. Interposition of dartos flaps to prevent fistula after tubularized incisedplate repair of hypospadias. Arab J Urol 2011; 9:123-126.

21. Yerkes EB, Adams MC, Miller DA, Pope JC, Rink RC, Brock JW. Y-to-I wrap: use of the distal spongiosum for hypospadias repair. J Urol 2000; 163:1536-1538.

22. Dodat H, Landry JL, Szwarc C, Culem S, Murat FJ, Dubois R. Spongioplasty and separation of the corpora cavernosa for hypospadias repair. BJU Int 2003; 91:528-531.

23. Hayashi Y, Mizuno K, Moritoki Y, Nakane A, Kato T, Kurokawa $\mathrm{S}$ et al. Can spongioplasty prevent fistula formation and correct penile curvature in TIP urethroplasty for hypospadias? Urology 2013; 81:1330-1335.

24. Sarhan OM, El-Hefnawy AS, Hafez AT, Elsherbiny MT, Dawaba ME, Ghali AM. Factors affecting outcome of tubularized incised plate (TIP) urethroplasty: single-center experience with 500 cases. J Pediatr Urol 2009; 5:378382.

25. Almodhen F, Alzahrani A, Jednak R, Capolicchio JP, Sherbiny MTE. Nonstented tubularized incised plate urethroplasty with Y-to-I spongioplasty in non-toilet trained children. Can Urol Assoc J 2008; 2:110-114.

26. Bilici S, Sekmenli T, Gunes M, Gecit I, Bakan V, Isik D. Comparison of dartos flap and dartos flap plus spongioplasty to prevent the formation of fistulae in the Snodgrass technique. Int Urol Nephrol 2011; 43:943-948.

27. Bhat A, Singla M, Bhat M, Sabharwal K, Kumar V, Upadhayay $\mathrm{R}$ et al. Comparison of results of TIPU repair for hypospadias with "Spongioplasty alone" and "Spongioplasty with dorsal dartos flap. Open J Urol 2014; 4:41-48.

28. Kocvara R, Dvorácek J, Díte Z, Sedlácek J, Molcan J. Comprehensive long-term analysis of hypospadias repair using vascularized flaps and tubularized incized plates- Report on 588 cases. Cas Lek Cesk 2005; 144:7-11. 